\title{
The Methods of Teaching Course Based on Constructivist Learning Approach: An Action Research
}

\author{
Sertel Altun ${ }^{1}$, Banu Yücel-Toy ${ }^{1}$ \\ ${ }^{1}$ Faculty of Education, Yildiz Technical University, Istanbul, Turkey \\ Correspondence: Sertel Altun, Faculty of Education, Yildiz Technical University, 34210, Istanbul, Turkey
}

Received: August 21, 2015 Accepted: September 7, 2015 Online Published: September 21, 2015

doi:10.11114/jets.v3i6.1047 URL: http://dx.doi.org/10.11114/jets.v3i6.1047

\begin{abstract}
This purpose of this study is to investigate how the course designed based on constructivist principles has been implemented, what actions have been taken to solve problems and what thoughts have arisen in the minds of teacher candidates with regard to the constructivist learning approach. In this study, an action research was employed which emanated from qualitative research designs. The participants in this study consisted of 55 science teacher candidates from the fields of biology, physics and chemistry for secondary education enrolled on the Teacher Training Certificate Program at one of large state university in Turkey. So as to collect necessary data for the study, reflection notes written by the teacher candidates, their products and a questionnaire to elicit opinions were used. The data obtained were then analyzed by using descriptive and content analysis methods. The acquired results demonstrated that on account of teacher candidates' increased exposure to the constructivist learning environment, their knowledge and professional skills increased over time. The teacher candidates outlined in their reflections on the process that becoming better acquainted with the approach did indeed make valuable contributions to their cognitive, academic and affective development. However, they indicated that factors such as inadequate provision of equipment in classrooms, oversized classes, individual differences in academic abilities of students and the centralized examination system prevented the successful implementation of this approach in the schools.
\end{abstract}

Keywords: Constructivist learning approach, teacher education, the methods of teaching course, action research

\section{Introduction}

In Turkey, the primary-school programs that have been introduced since 2005, have been revised and applied in accordance with the educational tenets of the constructivist approach. The constructivist learning approach has at its center an active learning processes permitting students to become responsible for their own learning and assisting them in become capable of constructing the knowledge that they require for their learning. In this regard, curricula that are based on this approach aim to create a learning environment in which students themself take responsibility for their own learning and learning concepts are created in accordance with students' own prior knowledge of topics in keeping with their own learning preferences (Jaworski, 1994; Marlowe \& Page, 1998; Von Glasersfeld, 1995; Woolfolk, 2004).

According to the constructivist approach, so as to give meaning to the experiences that one is exposed to within the learning process, knowledge and beliefs must be constructed by student himself. Within this process, the role of social interaction is important, both in terms of ensuring provision of life as well as providing meaning for that life. Through the constructivist learning environment, the students are supported so as to discover, discuss and interpret knowledge by themselves. In this learning environment, possibilities abound for the student to invent theories, test these out and, by way of his own thought processes, enjoy the opportunity to make reflections on his findings (Jonassen, 1999). In the creation and sustenance of learning environments that truly support the students' learning; the role of the teacher assumes supreme importance. According to Brooks and Brooks (1999), teachers must keep in mind five basic principles when creating constructivist learning environments: (1) posing or setting of a question that will awaken the interest of the students, (2) constructing learning around key concepts, (3) searching out and evaluating students' viewpoints, (4) adapting curriculum to address students' suppositions and (5) evaluating students' learning in accordance with the context that subject matter has been presented and received. Throughout this process, teacher's role as a facilitator guiding students on a journey of discovery and construction of knowledge by creating a constructivist learning environment gains importance. 
This is achieved by helping students to pass from an initial stage of drawing on their own experiences through active learning to another in which they create their own concepts of the subject knowledge.

In order to devise activities in accordance with the constructivist approach that help students achieve a successful outcome necessitates the design of relevant activities, the choice and use of the suitable equipment and materials, application of varied learning-teaching methods and the implementation of appropriate measurement and evaluation tools, in addition to the creation of suitable learning environments. Teachers should be required to undergo additional in-service training with view to enhancing their knowledge and application of that subject area so as to carry out their roles successfully, both prior to and following on from the delivery of particular subject material. For this reason, and with view to supporting the creation of constructivist educational environments and assisting students' harmonious adaptation to the principles of this approach, the Turkish Ministry of Education has provided a great number of in-service training programs for teachers after the new educational programs have been put into practice (Eren, Ozen \& Karabacak, 2009; Kildan \& Temel, 2008; Onen, Mertoglu, Saka \& Gurdal, 2009). Nevertheless, when one studies the application of the new approach within the classroom, it can be observed that the quality of the application of the approach has not yet reached an adequate level. Even teachers may understand constructivist learning on a theoretical level, it can be seen that they remain ill-equipped to apply it in a successful fashion in a real educational setting (Kasapoglu, 2010; Unsal, 2013). In certain studies carried out on this topic, it was highlighted that due to the fact that teachers themselves had throughout their own learning process been exposed mainly to traditional learning approaches, they themselves largely tended to prefer approaches that were teacher-centered in their nature (Kabapinar, 2012; Koc, 2006; Tsai, 2002).

As indicated in a study carried out by Karadag, Deniz, Korkmaz and Deniz (2008), not only focusing on in-service training of current teachers but raising teachers who display an affinity with the philosophy of constructivism at a pre-service teacher training is also important and necessary for successful implementation of the new education programs that have been developed in accordance with the principles of the constructivist learning approach. Nevertheless, studies examining the opinions of teachers regarding in-service trainings on the programs introduced in 2005 showed that majority of teachers described both in-service and preservice training as inadequate in this respect (Aytac, 2000; Bal, 2008; Boydak, 1999). To allow teachers to prepare learning environments based on constructivist principles in their classes, the principles of constructivist education need to be incorporated into the delivery of pedagogical courses and delivered as part of teacher training programs. In this respect, the need to create a clear model of the learning environments that teacher candidates are expected to create during their training gains importance. In other words, if teacher candidates are to be expected to create constructivist learning environments and guide their future students on their own learning journeys, designing teacher-training so as to become more synchronized with constructivist principles will be advantageous in helping future teachers to undergo a change in attitudes and behaviors so as to acquire the necessary skills and knowledge for successful future application of constructivism.

With this in mind, Abdal-Haqq (1998) specified two different educational models suitable for the constructivist approach. One of these models that are often observed in the present educational system is namely an introduction of how teachers facilitate learning in the constructivist approach and a description of methods, equipment and materials to be employed. The second model constitutes the experiential application of the approach whereby teacher candidates reconstruct their prior knowledge, they gain new skills by way of experiencing and give meaning to those experiences, and they have an opportunity for self-evaluation and a great amount of reflective activities. According to Kroll (2004), the views of teacher candidates need to be developed within the framework of a teacher-training program that should take the constructivist viewpoint as its very foundation stone. This state of affairs needs to be supported by offering practice-based training in accordance with this understanding and also by supporting them in terms of provision of materials and resources (Bagci-Kilic, 2001).

Applied research conducted with regard to the implementation of constructivism within teacher training mostly focuses on the second model of application. One of these studies, Koc (2006) carried out a qualitative study aimed at highlighting the roles of the teachers and learners and the interaction between both parties in a pedagogical course designed according to the constructivist approach. According to the results, it was observed that teacher candidates exposed to constructivist methodology in practice constructed and learned knowledge in a more meaningful way and were more active in lessons. Furthermore, it was demonstrated that students were involved in a greater level of interaction with both the instructor and their peers, they had a more positive attitude towards the course and developed affective characteristics such as self-confidence, respect for others and effective listening. However, it should be mentioned that those students who were not accustomed to playing active roles in class, demanded a return to the teacher-centered approach in the first two-weeks and showed improvement hardly. Nevertheless, there was an attempt to exert an influence of a learning environment that was conducive to the constructivist approach on the teacher candidates' learning process. In a study carried out by Taslidere (2013) on this topic, a set of worksheets including cartoon representations of the concepts contained within the topic was used in one study group on the topic of geometric 
optics. In another group, the lesson material was presented through a traditional approach. The group that followed the experimental approach and the group that were exposed to the traditional approach showed large differences in their level of understanding of the subject material, in favor of the experimental group. Similarly, in an attempt to reduce misconceptions, Birinci-Konur (2010) created an experimental group in which conceptual change texts designed in accordance with the principles of the constructivist approach were employed in a Chemistry course. The results of the experimental group were compared with two other control groups, one of which had not seen the subject material and the other who had been taught according to traditional methods, and it was found that the constructivist application had ensured the more effective understanding of the topic of chemical and physical change and its accompanying terminology and phraseology. In another study by Ozden (2012), the effect of the Teaching Practice course involving the implementation of reflective thinking on teacher candidates' preparation of a constructive learning environment was observed. Within the scope of the application, teacher candidates' lesson plans, the observation results of their presentations and the journals that they had kept during the course were collected and feedback was given. In such a way, it was revealed that this course made meaningful and permanent contribution to knowledge and skills regarding constructivism. In short, in the studies conducted, it became evident the act of introducing activities appropriate to the constructivist approach into the framework of teacher training had exerted a positive impact on teacher candidates.

Leading on from the explanations and studies discussed above, in this study, the Methods of Teaching Course was designed in accordance with the principles of constructivist learning approach so as to have teacher candidates to internalize constructivist approach and to use the principles of the approach in an effective manner in the future. The purpose of this study is to observe changes in teacher candidates themselves during the course designed in accordance with the constructivist approach, to take steps to address issues relating to interest, needs and any possible problems arising from the delivery of this course and then, at the end of the course, to evaluate the views of the teacher candidate with regard to the constructivist approach. The research questions giving direction to the study are as follows:

1. How was the learning-teaching process of the course designed according to the principles of constructivist approach implemented and what type of action was taken with regard to problems arising during its implementation?

2. At the end of the course, what were the opinions of teacher candidates regarding constructivist learning approach?

\section{Method}

\subsection{Design of the Study}

In this study, in order to observe the teaching-learning process of the course designed according to constructivist learning approach and the changes among teacher candidates within this process, to identify problems and to devise measures to address them, action research was conducted. Action research is one type of research design in which an educational problem is identified, an application is devised with view to finding a systematic solution which is then observed for the duration of its implementation, the proposals for different variations of this solution take shape in light of the data collected during this process and thereby the improvement of educational applications is aimed (Burns, 2010; Creswell, 2012). Within the scope of this study, both researchers and participants took place in the process together and action research was conducted based on the model proposed by Berg and Lune (2012). The model under discussion consists of the following stages: the identification of questions to be researched, the collection of data, the analysis of data, the sharing of the results of the analysis with the participants and the creation of an action plan. Within the scope of the research, activities were carried out with the aim of identifying the teacher candidates' prior knowledge of the topic under discussion and questions were specified with particular regard to the needs of the teacher candidates. In the second stage, data were collected so as to answer the questions under discussion by involving teacher candidates in a variety of activities and asking them to provide product (such as a lesson plan, small project or piece of writing). In the third stage, the products submitted by the teacher candidates were analyzed by the researchers and in the final stage feedback was provided to the teacher candidates and a plan of action was embarked upon. This process was repeated in a cyclical fashion for the duration of the course.

\subsection{The Participants}

The study group consisted of 55 science teacher candidates comprising the fields of Physics, Chemistry and Biology, currently enrolled on the Teacher Training Certification Program at a state university. Of them, 32 were female and 23 were male. 15 were from the field of Biology, 20 were from the field of Chemistry and 20 were from the field of Physics.

\subsection{Role of the Researchers}

Two researchers worked on the literature review, the determination of the methodology and the specification of the 
content to be covered in the lesson. The aim of the researchers was to ensure effective delivery of the course, to increase awareness of teacher candidates regarding the constructivist approach and develop accompanying skills. Therefore objectiveness was maintained in situations whereby positive or negative situations were encountered within the research process. One of the researchers was taught the course and maintained lessons for a total of 15 weeks. At the end of each lesson, the two researchers came together; the instructor presented her observations regarding the lesson delivered, they examined the products created by the teacher candidates, analyzed the reflective notes and journals and then, based on the results they devised an action plan. Furthermore, both researchers cooperated on the evaluation of the teacher candidates' products and on the development and assessment of mid-term and final exams. Finally, the analysis of the data, the interpretation of the findings, and the results and discussion sections were also undertaken and carried out by the two researchers.

\subsection{Data Collection Tools}

In the study, a data triangulation method was implemented involving the incorporation of more than one data collection method and technique at the same time. According to Maxwell (1996), in qualitative studies the collection of data based on numerous data sources reduces the risk of systematic errors. The data collection tools employed in this research were as follows.

\subsubsection{The Instructors' Reflective Notes}

Notes submitted by researchers are one of the data collection methods often employed in action research (Yildirim \& Simsek, 2013). The instructor who taught the course recorded her reflections weekly on the activities embarked upon that week, the positive or negative reactions of students and any problems encountered without including her own opinions.

\subsubsection{Teacher Candidates' Reflections}

Reflections were gathered from teacher candidates at the end of each assignment/task verbally and these are recorded together with the instructor's reflective notes. Additionally, the teacher candidates were asked to write their reflection for each of their product or piece of work that they submit in their portfolio at the end of the term. Within the scope of the study, the researchers utilized these reflections in both action plans and writing findings.

\subsubsection{Documentation}

Yildirim and Simsek (2013) underlined the fact that documents are sources of information that need to be used in an effective way in qualitative research studies and stressed the importance of documentation in providing required data for researchers without the necessity of conducting interviews and observations. Punch (2005) listed journals, letters, essays, personal notes, biographies, and autobiographies as documentation while Boke (2009) added visual and sound recordings, photographs, and drawings. In the study under discussion, the documentation included the products (lesson plans, posters and presentations etc) submitted by the teacher candidates.

\subsubsection{Questionnaire for Teacher Candidates' Opinions regarding Constructivist Learning Approach}

The questionnaire was developed by the researchers, each containing six open-ended questions. The aim was to identify the opinions of the teacher candidates with regard to the constructivist approach at the end of the course that had been designed according to constructivist approach. On the form, teacher candidates were asked to answer questions and to submit additional personal comments regarding: definition of constructivist learning, the skills that constructivist learning had helped them to gain (or not helped them to gain), the suitability of applying constructivist learning approach in teaching science, factors that prevent effective implementation of the constructivist approach, issues that they should pay attention to in the planning of their own courses in the field of science, and the suitability of the implementation of the constructivist learning approach within the setting of Turkish educational system.

\subsection{Procedure}

The teaching-learning process of the course in which action research was conducted was as follows:

1. The aim of the research was explained to teacher candidates and participation is ensured on a voluntary basis.

2. So as to identify the prior knowledge of teacher candidates with regard to the topic, case study which is one of the need analysis methods was conducted.

3. A draft syllabus was drawn up in accordance with the needs of the teacher candidates, it was introduced to them and it was finalized according to their opinions.

4. The implementation of the course was based on the constructivist learning approach during the whole term. Embarking from this approach, every instructional method and techniques were taught in an applied manner.

a. Whatever method or technique was undertaken in the lesson, the aim was to learn the principles of that method or technique under discussion by putting the method and technique into practice (for 
example if the subject under discussion was cooperative learning, the lesson was delivered in a cooperative manner with the aim that students learn by 'experiencing' the concepts and principles of the method).

b. Teacher candidates were then requested to prepare a lesson plan and/or perform activities in accordance with the method under discussion.

c. Opportunities were provided for all lesson plans and activities to be presented in class.

d. After each presentation, self-, peer- and instructor evaluations were carried out.

5. The Methods of Teaching Course is a four-hour lesson and is distributed into two sessions per week, with two hours in each session. After each two-hour lesson period, the researchers came together to share their observations on the lessons and to draw up a plan of action with regard to what they will undertake in the next lesson. The information regarding the weekly learning activities, observation and action plan are presented in Table 2 in detail.

6. At the end of the term, opinions were collected from the teacher candidates as to the characteristics and implementation of the constructivist approach.

\subsection{Data Analysis}

In the study, the instructor's reflection notes were presented in a descriptive form and the data gathered from the questionnaire were analyzed by content analysis method. Content analysis is carried out to arrive at common themes and relationships that can be explained by the data obtained. This method includes conceptualizing and coding data collected, arranging these codes and extracting themes that can account for these data (Yildirim \& Simsek, 2013). The data analysis process in this study was as follows:

1. The responses to the open ended questions in the questionnaire were first read and then read with greater care by one of the researchers who then encoded the responses. A code list consisting of all codes was then obtained.

2. After that, the codes and the data pertaining to those codes were then repeatedly analyzed and the code list then assumed its final form.

3. The codes in their final form were then examined with regard to their similarities and differences, the related codes were categorized and suitable themes were identified so as to be coherent to the meaning of these codes.

4. Following this, the other researcher encoded the data collected and similarly identified themes. Once this was completed, the two researchers came together and compared the codes and themes. Having reached consensus on those codes and themes where there existed discrepancies, they gave final form of the list of codes and themes (Appendix A). An example of encoding is given in Table 1.

5. In order for confidentiality, anonymity of students' name was ensured in transcripts by giving an ID to each student, such as S1, S2, S3 and so on.

Table 1. An example of data coding

\begin{tabular}{|c|c|c|c|}
\hline Responses & Code & Category & Theme \\
\hline \multirow{4}{*}{$\begin{array}{l}\text { Constructivist learning approach is an } \\
\text { instructional approach in which [student is in } \\
\text { the center], [teacher is a guidance], [student } \\
\text { learn by doing and experiencing, find } \\
\text { answer by searching him selves] [teacher } \\
\text { aims to teach propose solutions rather than } \\
\text { answer] }\end{array}$} & Student centered & Teaching-learning process & \multirow{4}{*}{$\begin{array}{l}\text { Definition of } \\
\text { constructivist } \\
\text { learning } \\
\text { approach }\end{array}$} \\
\hline & Guidance & Teacher roles & \\
\hline & $\begin{array}{l}\text { Learning by doing } \\
\text { and experiencing }\end{array}$ & Learning & \\
\hline & $\begin{array}{l}\text { Teaching how to } \\
\text { propose solutions }\end{array}$ & Teacher roles & \\
\hline
\end{tabular}

\section{Results}

\subsection{The Teaching-Learning Process of The Methods of Teaching Course based on the Constructivist Learning Approach}

The instructor's reflective notes with regard to the learning process, the products submitted by the teacher candidates and their reflections were examined and by taking these into account, a plan of action was taken in reflective meetings of the researchers. In Table 2, the activities undertaken every week, the instructors' observations during these activities, products of teacher candidates, and the plan of action decided by the researchers regarding the needs of teacher candidates are presented. 
Table 2. Learning activities, instructor's reflective notes and plan of action

\begin{tabular}{|c|c|c|c|c|}
\hline & Topics & Activity & Reflective Notes & Plan of action \\
\hline$\frac{\sqrt{2}}{3}$ & 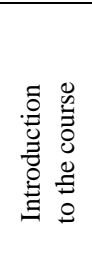 & $\begin{array}{l}\text { Case study } \\
\text { analysis }\end{array}$ & $\begin{array}{l}\text { In the case study analyses, it emerged that the teacher } \\
\text { candidates, in their own analyses, explained the roles of } \\
\text { teacher and students from traditional viewpoint. For example, } \\
\text { they made comments such as "the student cannot give an } \\
\text { answer as the teacher has not explained the topic", "the } \\
\text { students need to listen to the teacher more to learn the subject", } \\
\text { and "they must repeat more often", "The student couldn't } \\
\text { explain the problem as expected by the teacher." }\end{array}$ & $\begin{array}{l}\text { The content of the lesson was } \\
\text { devised as a draft according to the } \\
\text { needs of the students. For example, } \\
\text { to allow teacher candidates to } \\
\text { obtain the necessary theoretical } \\
\text { knowledge, a reading list was } \\
\text { prepared. }\end{array}$ \\
\hline
\end{tabular}

The content of the
lesson was formed
together with the

Application of 5E
teaching model.
Teacher
candidates studied
in a group.
Presentation of
the $1^{\text {st }}$ learning
plan

The cooperative learning method was applied.

Teacher

candidates studied in groups

Presentation of the $2^{\text {nd }}$ learning plan.

The plans drawn up by the groups were presented to the class. The mid-term
exam was set in a multiple-choice format and designed with the purpose identifying students' misconceptions.
It was observed that participation among group members was limited. In particular, it was realized that the ability of groups to create activities in the learning environment in the learning plans based on constructivist learning was weak.

In the learning plans, there appeared little consistency between objectives, teaching-learning process and evaluation processes. Within the learning process, objectives were restricted to the knowledge level. For example, in the learning plans, objectives were expressed at comprehension and application level, nevertheless in the teaching-learning process, these objectives remained at knowledge level. Furthermore, at the evaluation stage, the product evaluation was emphasized but process evaluation was not taken into account.

It was observed that teacher candidates derived a great amount of satisfaction from this process. By putting the method into practice, it served to help teacher candidates to internalize the topic.

It was observed that the principles of the methods had been adopted into the plans and expressed in the correct way. Nevertheless, raising objectives to the comprehension level was still weak and the homework devised to relate the topic to real life was also weak and insufficient. For example, on the topic of the 'Processing of Acids and Bases', the groups had set out the principles of the method to their lesson plans very well, however when it came to assigning homework that would allow students to transfer that knowledge of acids and bases to real life, it was observed that the assignments were unsatisfactory.

Teacher candidates were successful in answering questions related to the characteristics of the methods. Nevertheless, in comparisons between certain concepts: e.g. model and strategy, some mistakes were made. As for case study analysis, they had misconceptions in particular on the topic of the precautions that had to be taken by a teacher in a constructivist environment.
It was decided to create four learning plans and four activities, to distribute the course notes prepared by the instructor and the reading lists on the topics to the teacher candidates to provide material source.

A learning plan based on the $5 \mathrm{E}$ model was requested for the next lesson from the groups.

It was decided to find and let them examine example activities that teacher candidates could use in the preparation of learning experiences so as to raise the level of objectives to comprehension and application level. Written notes and recommendation for improving lesson plans were given.

It was decided to ask teacher candidates to prepare a learning plan for their own lessons based on cooperative learning method.

It was decided to explain the groups what was meant by a homework assignment related to real life and how such assignments could help to raise students to a higher cognitive level. Teacher candidates should learn how such homework is created, with clear explanations of each step of the process. Teacher candidates would be requested to bring in examples of their own and to focus particular on examples that help to enhance or underpin a subject. It was also decided to hold a tournament based on this topic.

The teacher candidates were requested to produce a concept map for the next lesson with regard to their misconceptions and to evaluate the other's concept map together in pairs in the class. They were also asked that a student would draw a concept map on the board with the direction of other students and a moderator. 
Table 2. Cont'

\begin{tabular}{|c|c|c|c|c|}
\hline & Topics & Activity & Reflective Notes & Plan of action \\
\hline $\begin{array}{l}\infty \\
\frac{1}{0} \\
\frac{d}{j}\end{array}$ & 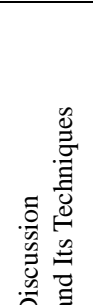 & $\begin{array}{l}\text { Discussion method } \\
\text { and techniques were } \\
\text { taught. Students were } \\
\text { separated into groups } \\
\text { and they were ensured } \\
\text { to learn the topic of } \\
\text { discussion method and } \\
\text { techniques by using } \\
\text { the } 5 \text { Emodel }\end{array}$ & $\begin{array}{l}\text { In the discussion held with the teacher candidates, it was } \\
\text { emerged that techniques such as "brainstorming", } \\
\text { "debate" and "large group discussions" were known } \\
\text { generally but they did not know discussion techniques } \\
\text { such as "buzz groups", "six thinking hats" or "panel". } \\
\text { They expressed that these techniques all resembled each } \\
\text { other. They also expressed that they can use "six thinking } \\
\text { hats", "SCAMBER", "brainstorming" and "debate" } \\
\text { technigues in their own lessons more easily Teacher }\end{array}$ & $\begin{array}{l}\text { Furthermore, lesson plans prepare } \\
\text { in accordance with the topic and the } \\
\text { related articles were suggested to } \\
\text { the teacher candidates for further } \\
\text { reading. As an application of } \\
\text { discussion method, it was decided } \\
\text { to hold a debate on a specific topic } \\
\text { in the following week's lesson. }\end{array}$ \\
\hline
\end{tabular}

techniques in their own lessons more easily. Teacher candidates were also provided with examples of discussion techniques such as panel, cross-panel, conference, open session, seminar and symposium" by establishing the links to discussion programs on tv in order to ensure them to better understand.

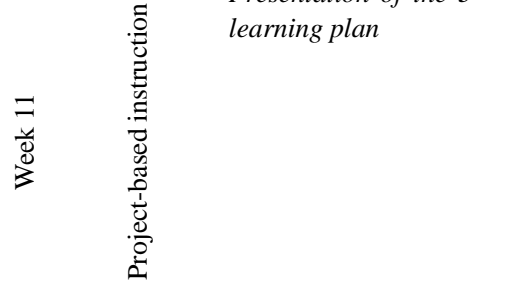

A student was selected from each group and

two groups were determined by drawing names. These groups went onto debate the topic "Which approach should be used in Turkish education system: The

Traditionalist or the Constructivist?"

\section{Examples} project-based instruction were given and they were requested to examine these examples. They were also asked to determine the general characteristics of PBI by preparing poster study.

Presentation of the $3^{\text {rd }}$ learning plan

The teacher candidates emphasized that constructivist learning is more advantageous as it focuses on student, ensures long-term retention of knowledge and gives more initiative to teacher. On the other hand, they stressed that traditional education is more effective since it can be used in crowded classes more efficiently, it is possible to implement a common curriculum, it is appropriate for goal-oriented systems and teacher are trained in a traditional approach. The groups were evaluated on the following criteria: their 'persuasiveness', 'formation of new theses', 'fluent speaking, 'creation of excitement' and in the end, the group supporting constructivist learning won the debate.

It was observed that the groups expressed the general characteristics of the method correctly but had lack of knowledge about issues such as possibility of assigning project to groups, importance of reflection and periodic observation and establishment of interdisciplinary relationship.

It was observed that the teacher candidates were successful when they worked together with those from other disciplines. It was observed that some groups were weak in the division of the project into clear steps and in determining their evaluation criteria.

By using drama or role play in connection with their own lessons, teacher candidates were asked to create a plan and implement it.
The groups initially experienced difficulty in creating activities related to the selected topic. It was observed the biology teacher candidates were at first more successful in suggesting activities about topics such as "blood groups", "photosynthesis" and so on, followed by the physics teacher who put forward topics like "resistance" and the chemistry teachers who came up with creative examples such as "cells and structures" and "The Periodic Table". It was observed that teacher candidates had great fun in the drama enactment stages.
It was observed that the teacher candidates showed increased participation in-class activities, excited, enjoyed and preferred more tournament activities. Therefore, the researchers decided to include more such activities in future lessons.

By taking into account their lack of knowledge, the instructor illustrated the method on an example design and focused the associated concepts and principles. Furthermore, example designs were distributed to the groups and they were asked to analyze and evaluate the designs in terms of the principles of the method and then to present their findings to the class. For the next lesson, they were asked to prepare their $3^{\text {rd }}$ learning plan based on project-based instruction.

It was decided to give explanation about the importance of determining the list of evaluation criteria in the evaluation of projects and how projects should be holistically evaluated. It was also decided to show good example plans prepared by the groups in the class.

To allow teacher candidates to see more examples in relation to the topic, more example studies and articles were distributed. 
Tablo 2. Cont'

\begin{tabular}{|c|c|c|c|c|}
\hline & Topics & Activity & Reflective Notes & Plan of action \\
\hline$\frac{n}{\frac{y}{0}}$ & 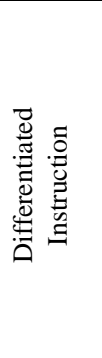 & $\begin{array}{l}\text { The basic principles } \\
\text { and techniques were } \\
\text { applied through the } \\
\text { use of the 'station } \\
\text { technique.' }\end{array}$ & $\begin{array}{l}\text { The teacher candidates all expressed that this instruction } \\
\text { was appropriate for their own fields, individual } \\
\text { differences were particularly an important factor in their } \\
\text { courses and they acquired advices about what they should } \\
\text { do in this respect. It was identified that the teacher } \\
\text { candidates were weak in regard to which assessment tools } \\
\text { they should use so as to identify individual differences. }\end{array}$ & $\begin{array}{l}\text { It was decided to give information } \\
\text { about measurement and evaluation } \\
\text { methods and techniques that can be } \\
\text { employed for identifying students' } \\
\text { learning styles, readiness level, and } \\
\text { individual areas of interest and ask } \\
\text { teacher candidates, for the next } \\
\text { lesson, to prepare their last learning } \\
\text { plans in accordance with the } \\
\text { differentiated instruction principles. }\end{array}$ \\
\hline $\begin{array}{l}\frac{ \pm}{v} \\
\frac{\Delta}{8} \\
\frac{d}{3}\end{array}$ & 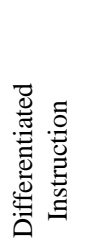 & $\begin{array}{l}\text { Presentation of the } 4 \text { th } \\
\text { learning plan }\end{array}$ & $\begin{array}{l}\text { In general, compared to their initial plans, their last plans } \\
\text { were more creative, enriched with more materials and } \\
\text { included a number of activities ensuring students to reach } \\
\text { higher cognitive level. In the plans, attention was paid to } \\
\text { the cognitive differences among students, while little } \\
\text { importance was attached to the affective differences } \\
\text { between students. }\end{array}$ & $\begin{array}{l}\text { Examples were requested from } \\
\text { students with regard to the topic. }\end{array}$ \\
\hline $\begin{array}{l}\frac{n}{3} \\
\frac{y}{0} \\
\frac{d}{3}\end{array}$ & 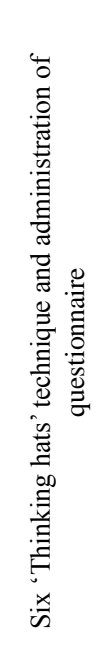 & $\begin{array}{l}\text { 'The constructivist } \\
\text { learning approach' was } \\
\text { evaluated by using the } \\
\text { 'six thinking hats' } \\
\text { technique. }\end{array}$ & $\begin{array}{l}\text { The following explanations arose with regard to the topic: } \\
\text { Yellow: We will rise to the highest level. } \\
\text { White: Putting students at the center of learning is an unavo } \\
\text { Red: A more active and exciting class environment. } \\
\text { Green: Lessons shouldn't just be done in class; knowledge } \\
\text { source where it is originated from. For example, to learn a } \\
\text { and learning from the doctor or lab assistants. } \\
\text { Black: The method is very difficult to apply in crowded cla } \\
\text { approach. It is an additional load. If you leave the learnin } \\
\text { anything. }\end{array}$ & $\begin{array}{l}\text { dable fact. } \\
\text { hould be learnt in its real setting and } \\
\text { out blood groups by visiting a doctor } \\
\text { process to children, none will learn }\end{array}$ \\
\hline
\end{tabular}

\subsection{Opinions of Teacher Candidates with regard to the Constructivist Learning Approach}

Five basic themes were identified as a result of the content analysis of the responses. These were the definition of the constructivist learning approach, the contributions of the approach to students, limitations of this approach and the implementation of the approach in teaching science and in the Turkish educational context.

\subsubsection{The Definition of the Constructivist Learning Approach}

In the comments made by teacher candidates with regard to definition of the constructivist learning process, it was observed that definitions were largely made concerning the constructivist as a theory of learning. In their definitions, great emphasis was also attached to the student, teacher, and teaching-learning process. Moreover, the constructivist learning approach was seen and expressed by using terms such as an approach, a method, a form of teaching, a model and a learning mechanism.

In the definitions that were connected most closely with constructivist learning theory, the approach was described as the formation of knowledge based on the student's creation of ideas, arrival at knowledge as a result of his own study and his construction of this knowledge, the construction of knowledge through experiencing, searching, questioning, and discovering and the formation of knowledge based on prior learning.

"(constructivism) is an approach in which through learning knowledge by applying and doing, the student leaves a rote-learning system behind, and acquires the ability to think, reason and ask questions..."S28

"The constructivist approach to learning.....is an approach that takes student's prior knowledge as the basis, ensures student's active participation in lesson and supports his learning through discovery rather than presenting 
information directly." S46

When defining the constructivist learning approach, its features related to teachers' and students' roles and structure of the teaching-learning process were also mentioned. Students' roles emphasized by the teacher candidates were being active and being responsible for their own learning. As concerns the roles of teacher, teacher as a guide was highlighted first and foremost by the majority.

"Constructivist learning is not a teacher-centered, but a student-centered instruction. Teacher is a guide and student arrives at information through his own endeavors. Teacher demonstrates to student how to arrive at that knowledge. In other words, the student is constantly active." S10

In addition to the guidance role of teacher, when describing constructivist learning, the approach was termed as one in which the teacher does not provide knowledge in a ready-to-consume way, does not constitute the sole source of knowledge, teaches the student to produce several solutions to problems rather than giving answers, makes students' active, ensures their participation, leads them to search, prepares and designs an environment appropriate for the construction of knowledge, provides feedback, has more responsibilities and are required to be qualified in terms of pedagogical knowledge and intellectual skills.

“...In order to provide education using this approach, more work is required of teachers. Teachers must both know this method so well and his knowledge of the theoretical dimensions of his area of specialization and intellectual knowledge must be so fine-tuned and developed that he can attract the interest of students in the correct manner towards the topic under discussion." S9

"(The Teacher's role) is to provide student to discover the required knowledge by himself through the activities teacher devises. In that respect, teacher only plays the role of a guide. The knowledge to be attained may be conveyed to the class through a number of media: stories, videos, jokes, stories or simulations. At the end of the presentation stage, he explains to the students what they have to do to 'discover' the knowledge contained within. Through the teacher's explanations, this knowledge is deepened and intensified. In the final stage of the process, an evaluation is conducted, and the topic is brought to a conclusion" S40

On the other hand, this learning approach was also defined with its teaching-learning process features. The teacher candidates characterized the approach by describing learning environment as a free, comfortable and dynamic setting for constructive learning. According to teacher candidates, in the teaching-learning process, individual differences, students' interest and needs are taken into account and a milieu is formed appropriate for cooperative and student-centered learning. The approach was also defined as teaching-learning process in which problem solving and discussion methods are used, technology is frequently utilized, school is the life itself or preparatory for life and both the process and products of learning process are evaluated.

“...for students schools must be the life itself....." S30

“... It is a system that takes form with the construction of the teaching model by taking students' needs, interests and desires into account." S52

\subsubsection{The Contributions of the Constructivist Learning Approach to Students}

From the responses given by the teacher candidates related to the constructivist learning approach and the skills attained through exposure to it, the approach can be seen to make contributions in three key areas: cognitive, academic and personal development. As concerns cognitive development, it has been identified that the constructivist learning approach has positive contributions in developing the following aspects of the students: having thinking skills, research skills, problem solving skills, interpretation skills, discussion and debate skills, approaching events and occurrences from different perspectives, respecting for different or opposing points of view, solving problems individually, evaluating life and problems, raising curiosity, being able to understand complex information and to answer 'higher-level' questions.

“...Thinking, questioning, producing, problem solving, posing questions, research skills" S44

“...Thinking differently, demonstrating respect for opposing ideas, presenting one's ideas openly and clearly, problem solving, the ability to look at problems from a different perspective, acquisition of research skills, asking questions, the ability to think objectively." S54

Concerning academic development, participants expressed the view that a number of skills were gained in this regard including: becoming more active, participating more, having self-regulation skills, learning to learn, taking responsibility for one's own learning, retreating from memorization, relating topics to real life, using knowledge and transforming it into a 'product', asking questions, learning by doing and experiencing, discovering and constructing information, lasting and meaningful learning, refraining from laziness, having positive attitude towards courses and 
being more interested in the subjects studied.

"It is a teaching approach in which students obtain knowledge through their own efforts and in which they construct knowledge themselves" S2

"It raises the self-confidence of even introverted children so that they are satisfied in what they learn and become happy. Compared to traditional methods, they do not forget subject matter that they learned." S34

Finally, the view was also put forward that the constructive learning approach contributed to personal development in many ways. Among the examples cited were the development of self-efficacy, self-confidence, cooperation, presentation skills, ability to express oneself, an increase in democratic values, respect for oneself and self-actualization.

“...Ensures the emergence of self confidence in passive students and compels them to develop the thought that 'I too can do it'..." S21

“...(the student) learns to take responsibility in group activities and learns to work in a spirit of cooperation. If appropriate targets are assigned to reserved students, they can overcome their difficulties" S25

Furthermore, one teacher candidate highlighted positive aspects of the approach by drawing on his experiences in the Method of Teaching Course and compare the constructive approach with the existing education in most of today's schools.

“..... We were all educated according to traditional approaches. The knowledge we learned was merely memorized. The teacher explained and we listened. When we were to have an exam, we simply memorized information and passed the exam. The constructivist educational approach does not rest on the memorization of information or knowledge. At the school where I am currently doing my training, this approach is put into practice. I can observe at first hand the difference with the students (that I am acquainted with). Through performance-based homework, students can produce excellent products. Within the learning process, the students participate actively in the lessons. With posters that they have produced in class, they do presentation and the other students can participate into the lesson very well. They conduct experiments in the class. When I contrast all these with the experiences of my own education, it becomes self-evident that constructivism is necessary. Another example, activities we did in this course (the Methods of Teaching Course) reveal that knowledge that were learned by doing and experiencing is not forgotten. I am sure if I had just read the information about methods and techniques such as tournament technique, debate technique we did in the class from books, I could not learn so much" S40

\subsubsection{Limitations of the Constructivist Learning Approach}

Although a great number of advantages were mentioned with regard to the constructivist learning approach, various limitations were also cited by respondents. The teacher candidates indicated that they felt that constructivist learning may on occasions exert a negative influence on the development of students' skills and this situation was mainly caused by the individual differences of students' readiness level and the overcrowded classes. It was indicated that when this approach is exposed to students whose cognitive and readiness levels are different, their participation would be difficult and they would not show achievement. Concerning crowded classrooms, they stated that as participation of all students would not be possible, there would be students who did not understand.

“...It will not be possible for students with different cognitive levels to participate in classes at the same time and slow learners will not be able to perform as successfully (as their peers with higher cognitive levels..." S7

"...On account of the fact that classes are so crowded, it will prove difficult to reach each student. While certain students are active, this may actually prevent the active participation of students who are quieter by nature." S49

Another negative factor cited was the group work that forms an essential pillar of the constructivist philosophy as this may constitute a disadvantage in particular for those students who are not inclined to working in groups and may cause students to lose their competitive incentive because of supporting cooperation in groups.

"...If a student supports to work alone rather than with a group, he would show little interest towards group-based activities. This affects learning level negatively" S43

Furthermore, teacher candidates also focused on another related issue that the implementation of the constructive learning approach may lead to a regression in the students' listening skills and learning by listening. These views can be evaluated as a reflection of the traditional understanding of education.

"....It upsets the position and relationship between the listener and the learner. In a system that raises self-confidence as a virtue, it may have the opposite effect on the gentle, cautious personality...in the sense that it (harmfully) raises individualism (as a goal)..." S20 
At this point, problems relating to teachers were shared. Issues were identified such as the danger that students may wrongly think that after having acquired knowledge, they no longer needed teachers; the worry that by excessively increasing self-confidence, the student may lose respect towards teachers; and problems that caused by teachers who do not adopt the constructivist learning approach and who do not apply it systematically and properly.

"..The child may think, on being able to arrive at knowledge easily or being able to access knowledge at any moment, that he has no need of the teacher" S46

“...The student may at times lose respect (for others) on account of excessive self-confidence." S52

\subsubsection{The Implementation of the Approach in Teaching Science}

The teacher candidates also expressed many views with respect to the applicability of the constructive approach in teaching science. On evaluation of these opinions, they can be divided into the following three main areas of focus: (a) the necessity of applying the constructivist learning approach in science teaching, (b) factors that prevent its successful implementation, and (c) factors to be taken into consideration when putting the approach into practice. All of the participants indicated that generally speaking they felt that this approach was appropriate for application in the field of science education. In particular, on account of the fact that science lessons include subjects that are derived from real life and involve activities such as experiments, making observations and analyzing, conducting research, and learning through doing and experiencing the constructivist approach is a most suitable approach to be implemented.

"...As science education is based on observations and experiments, the student during the learning must obtain knowledge by searching, discussing and making use of various methods and techniques. Science education can only reach its goal through (the application of) constructivist learning." S24

“...Science courses include many things from real life. A large part of our life contains (direct relationships with the topics of physics, chemistry and biology. For this reason, if the lesson is conducted in keeping with the principles of the constructivist approach, the student will obtain knowledge not from books, but rather from 'himself'. He will learn by conducting experiments, observing nature and by doing such things will not merely memorize information, but instead learn knowledge in a way that is lasting and meaningful". S40

"Science courses are ones that are surrounded by many prejudices. The subject is in need of the attractive, unusual methods that are contained within constructivism to destroy these prejudices and to demonstrate just how enjoyable and beneficial the discipline of science is". S18

In the section above, the teacher candidates, by associating real-life needs with the structure of the lesson, demonstrated that they felt that the constructivist approach was suitable for application in teaching science and would also make a positive and lasting contribution to the quality of teaching and to scientific thinking. As regards the quality of teaching, a number of positive contributions that the approach could make to improve the present situation was cited: lasting and effective learning, the concretization of formerly abstract concepts, learning through 'doing and experiencing', the raising of students' levels of participation and activity in class, the creation of a productive and beneficial learning environment, the motivation of students and a moving away from traditional rote-learning approaches.

"In the field of physics a great number of subjects cannot be learned properly, on account of relying on the memorization of subject matter. However, constructivist teaching is appropriate for Physics and other science courses in the sense that it reduces memorization to a minimum."S32

“....The constructivist approach is an approach that ensures support to students in conceptualizing abstract knowledge in science lessons and most particularly in the field of chemistry and constructing correct schemes by understanding." S33

It was also mentioned in the above context that the constructivist learning approach is advantageous in developing scientific thinking and analytical thought, reasoning, establishing relationships between cause and effect, designing and producing projects.

“....For a lesson that requires students to think analytically, it is logical to apply an approach that forces the student to think in an analytical fashion. Constructivist teaching is an approach extremely appropriate for science teaching in the way that it encourages the student to obtain knowledge by himself, renders laboratory work more effective and forces teacher to convey extremely abstract topics in chemistry and physics courses in an understandable way" S29

The teacher candidates, while evaluating the suitability of applying the constructivist learning approach in teaching science positively, also brought attention to the existence of factors which may prevent the successful implementation of the approach in the related courses such as Biology, Chemistry, etc. One of these factors is that some content of the courses in the field of science is not suitable for this approach such as topics that students encounter for the first time, a 
content base that incorporates a great amount of learning and calculation of formula or experiments that they would do firstly.

“...For certain topics in chemistry lessons such as heat conduction or in biology lessons such as description of different species (e.g. extinct species) the method may prove problematic in not allowing students to obtain key factual information" S 14

"I do not think that the approach is suitable for biology lessons. The teacher must for some topics, for example, the respiration process in plants, first explain the process and parts of the plant himself and only after listening to the teacher can students carry out experiments" S54

Other important limiting factor was the limited amount of time allocated to covering all elements of the curriculum and the large class sizes present in Turkish schools.

"The curriculum may at times be limited. There may be a yearly plan and the teacher is required to deliver lessons according to the order contained in the plan. However, implementation of this method requires a great deal of time. In this case, teachers do not prefer." S37

The view was also expressed that the successful implementation of the method requires well-informed and well-trained teachers. However, in Turkey teachers either lacked the suitable background or training and adopted traditional approaches to teaching; even if they did possess the background or qualities to be a constructivist teacher, they were forced to apply teacher-centered instruction on account of inadequate conditions in the school environment.

“...Due to insufficient infrastructure and teachers who have been trained in accordance with traditional teaching models, there exist a number of inadequacies in attempting to create a (constructivist) educational environment." S39

“.... Certain teachers and students encounter difficulties in trying to understand the (constructivist) system. If a student is used to his teachers, explaining a topic in a direct manner, the student will come to expect this from his teachers. If the topic that they are supposed to search does not attract their interest, they may lose attention to that course. This is due to the fact that a teacher who does not correctly understand the system may end up placing the total burden of learning onto the student himself." S52

Six basic principles were cited by teacher candidates that teachers need to take into account when planning a course in the field of science according to constructivist principles: characteristics of students, features of learning environment, course objectives and content, teaching-learning process, measurement and evaluation dimension and personal characteristics and attributes of teachers themselves. The characteristics of students that the teacher candidates would take into account were classified as their prior knowledge, needs, competencies, levels, socio-cultural characteristics, individual differences, and attitudes to the course.

"When planning such a lesson, by applying techniques such as questioning in order to ascertain students' levels, it can be identified exactly what subject matter students can absorb and at what level students can be expected to reach." S21

As regards the learning environment, the choice of equipment and materials, adequacy of materials, class sizes, conditions and structures were determined by the teacher candidates as issues that needs to be taken into consideration:

"The physical and economic opportunities at hand" S28

"I pay attention to what will be effective over a long time and (materials) that I can use in a beneficial way" S32

"...If I am to direct or guide a lesson, I am forced to pay attention to the class size. While one student is learning, I should not ignore another student in classes with large student numbers. For this reason, it is necessary to create suitable conditions for learning."S37

Furthermore, in addition to setting out the skills and knowledge to be attained and the suitability of the topic, it was identified that the following factors must be taken into account for successful delivery of a constructivist based lesson: determining appropriate teaching methods, techniques and materials, relating subject matter to life, providing student participation, selecting attractive topics that spark curiosity, creating scenarios or situations and thus encouraging students to research, guiding students to solve problems through discovery, encouraging them to learn through research, allowing opportunities for observation, providing variety in lessons, establishing relationships between old and new knowledge and linking that with experience in real life, reflecting and revising previous material and providing clues to assist in the students' learning process.

"...The student thinks about what he can gain from the study of a given subject and how he can develop himself. I contribute to their development by giving each student topic to study according to this principle and by facilitating 
them research." S37

"....During the engage stage in which there is the creation of an overall framework to their learning process (linking personal and theoretical knowledge), I am careful to provide common every day, yet attention-grabbing examples from real life - In the explore stage I provide apparatus and equipment for students that ensure that student is easily able to arrive at the knowledge he needs.- In the extend stage, once again through the provision of striking example and through mind games and puzzles as well as discussions and debates, I ensure that students are able to reconcile the knowledge with what they have learned previously."S50

Although, there were a few teacher candidate pointing out evaluation dimension, those candidates mentioned that they would pay attention to what extent student understand and how their comparison and reasoning skills and evaluate the teaching-learning process.

“....at the evaluation stage, without only asking questions, preparing conditions that students would use knowledge that they learned in learning environment or was constructed in a qualified way and evaluating this process." S39

"....Activities that student did would be real evaluation for me." S45

Finally, it was mentioned that with regard to personal attributes or qualities of the teacher, importance should be attached to the following factors: behaving in an even-handed and democratic manner, being expert in the field, being creative, behaving and speaking carefully in class and sharing his views with other teachers.

"As I will play the role of a guide in this teaching approach, I must be totally competent and expert in the subject I am teaching. I must collect information concerning the projects that are to be conducted in class." S10

"...In particular it is necessary to search the related studies about biology. I must follow current developments in my field so as to introduce them into the classroom environment and so create an environment for discussion with my students. I must also be creative in this regard" S26

Nevertheless, it was noteworthy that the traditional approach was reflected in the comments made by two teacher candidates about how they will implement the constructivist approach. One of them indicated that he would use reinforcement schedules in his classroom. The other assigned the students a project topic, but instead of stimulating them to carry out research, asked students to present the topic to the class. This situation indicates that they confused the constructivist approach with a 'project assignment'.

"As it is important for every student to realize the importance of information he presented and for motivating them, I will use reinforcements" S52

"When planning the lesson according to this approach, every week the students make presentations in groups; I assign research topics and ask them students to present these research assignments in class. I gave grades to their presentations. I encourage students to ask their friends questions and I help to guide students in differentiating between the correct and wrong." S42

\subsubsection{The Implementation of the Approach in the Turkish Educational Context}

In their evaluations of the constructivist learning approach within the context of Turkey, the teacher candidates cited the problems that prevented application of the approach and stemmed from the qualities and characteristics of teachers, the school and class environment, the structure of the lesson, the curriculum and even the education system itself.

Common problems that were indicated included the impossibility of putting the approach into practice on account of teachers' lacking sufficient training with regard to the approach as well as lacking adequate information technology skills. In addition, there was mentioned the predominance of teachers, who had reached retirement age and were too 'old' for the profession, were traditionalist in outlook closing their minds to innovation, prejudiced in their mindset and lacked motivation. Furthermore, it was indicated that some teachers avoid commitment by not exerting themselves excessively and wish to bother themselves with lesson planning. These teachers lacked the ability to make the learning environment attractive for students and did not possess the capabilities to ensure student participation. These and other matters were cited by teacher candidates.

"..Unless those teachers who have reached the age of 60 are not sent into retirement and class sizes are at least halved, this (constructivist) approach cannot be applied. The fact that the teacher is not open to innovation, is prejudiced in his outlook and does not know how to apply the necessary methods are all factors that prevent the application of the approach" S2

"..The fact that the teacher does not believe in this approach, and the fact that the teacher was himself educated using classic methods means that he wants to continue with the (traditional) approach. In constructivist teaching the teacher must come to lessons fully prepared, whereas in the classical approach the teacher merely explains and 
then passes to the next topic" S34

"...It is a teaching system that requires a great deal of time and which renders lesson planning difficult" S43

When considering how students may act to prevent successful implementation of the approach, the fact that classes are not homogenous in terms of their students' readiness level for lessons, the individual differences between students, the inadequacy of prior knowledge on the part of certain students and the presence of students who have become accustomed to learning only by listening may prove problematic in attempting to deliver constructivist-based lessons:

"...It should be implemented but in my opinion it is difficult and requires long time. Because the dismantling of the shell of the model that has prevailed until recently in which the student learns only by listening will not prove easy." S15

"In the school in which I did my teaching practice, I observed that the classes were extremely heterogeneous. This situation arose from the fact that the students did not possess the same cognitive levels of understanding. In such situations, the construction of knowledge by students in the same way, prevents the students from reaching the same conclusion and so limits the success of this approach." S50

In the school and class environment, the following reasons were mentioned that prevented the successful implementation of the approach: overcrowded classes, the positioning of furniture and equipment in the classroom, the types of equipment, apparatus and materials used and inadequacies in the physical condition and infrastructure of the school.

The constructivist approach cannot be applied because classes in schools in our country are very crowded. In most schools in Turkey, there is a problem with class sizes. On account of the class sizes being so large, the constructivist approach is not appropriate. Every student does not get the same right to talk and participate." S1

"...As the duration of a lesson is 40 minutes and because of the value of this time, and large numbers of students in the class, active learning is ensured for certain groups in the class, but not for the remaining students." S36

With regard to the structure of the course and curriculum, the difficulty of applying the approach into every topics, the obligation to complete the curriculum and in this context the limitation on time were cited most often as the most pressing problems facing the constructivist teacher.

“...The fact that we have such an intensive curriculum, the subjects contained in it are very wide and comprehensive and there is a real problem concerning time....The sheer number of subjects and the intensity by which they are taught serve as obstacles to transitioning completely to the constructive approach". S11

"..The fact that a lesson lasts only 40 minutes and time is therefore very valuable. As a physics teacher, there is a curriculum that I am supposed to cover and complete. The nature and length of this program prevents the application of the constructivist approach.” S36

Finally, there are also problems that originate in the education system in Turkey itself. These problems were listed as the lack of necessary learning resources, the inadequate allocation of financial resources to education, the rootedness and consolidation of an education system based on rote-learning, the lack of effective and adequate in-service training on the constructivist approach, coordination problems in terms of administration, and the negative effects of the exam system. With regard to the examination system, the negative effects of such a system both on teacher training and on the applications and activities conducted at schools were mentioned. For example, due to the fact that KPSS (Turkish Public Service Selection Exam) is focused largely on theoretical matters, teacher candidates and education faculties attach more importance to theoretical aspects than to practicing teaching skills needed for the profession. In terms of schools, it was indicated that since the centralized exams includes questions at knowledge level and schools give emphasize on these exams, these exams affect negatively the use of teaching methods encouraging higher order thinking skills.

"I think that teachers who have been raised within the traditional system and came from an educational background that largely favored rote learning must first adopt the principles of the new system before they can put them into practice. As far as I am concerned, the education I received up to university was the traditional, and even at university we studied through memorization. However, I would like to say that this teacher training certification program I receive was very effective (for my development)." S25

"...The fact that new teachers and we did not see constructive teaching at first hand during our primary or middle school education." S29

“...At school the delivery of lessons using the constructivist approach and then measuring success according to rote-learning based state examinations such as YGS , LYS and TEOG ( state wide examinations required to allow entrance to next level of education for university, foreign-language study and high schools respectively) is not 
appropriate." S35

"Furthermore, the positive guidance provided by the Ministry of Education to the schools in certain regions under its remit but the lack of guidance in other regions. The government attaches importance to some regions while it ignores the importance of new approaches in others. This situation does not let to implement this approach." S36

"This situation is most evident when one looks at the composition of staff members at all levels of the Ministry of Education. Within the education system, everyone from the teacher to the administrator find themselves in a 'vicious circle'. In such a situation, in-service training remains nothing more than a formality and the traditionalist mentality cannot be broken out of. The summary of the situation is that the introduction of new applications within this system is not more than a 'patchwork job'. Change must be applied in a serious way from top to bottom. When one pays attention to the awkwardness and clumsiness of the structure of the Ministry of Education, without breaking the classical teaching model that has taken root in the minds of those within the ranks of its personnel at all levels over the years, no progress can be made. With this in mind, experienced experts from their own fields of study must force those involved in education from the lowest to the highest levels to undergo a serious program of retraining and take measures to ensure reform is carried through." S55

There were also numerous teacher candidates who indicated that they felt it was possible for the approach to be implemented in the Turkish educational system providing that certain conditions were satisfied. In the event of a reduction in class sizes, provision of sufficient learning materials, the guarantee of pre-service training to teacher candidates and in-service training to existing teachers, accompanied by the sufficiently equipping teachers with the required skills and knowledge, teachers would be able to successfully apply the approach in a spirit of idealism, self-sacrifice and patience. A small, yet significant number of the teacher candidates also expressed the view that they felt that Turkey was more advanced in comparison with many other countries, and that there were schools that would be able and indeed are presently able to apply this approach and there also exist numerous teachers who already possess the necessary knowledge and skills to be able to put this approach into practice.

“.... I think that Turkey is more developed compared to a large number of countries. I work in a private school. It is a school that attaches importance to the implementation of constructivist education. In many state schools where my friends work, the approach is also applied. When I studied the yearly plans issued by the Ministry of Education, I saw that they had prepared a plan that encouraged the students to learn through questioning." S5

“..In particular, class sizes need to be reduced. Materials need to be provided that allow students to learn visually. However, together with such changes, teachers need to be trained in accordance with a constructivist manner. A teacher who has not been raised according to such principles and does not know how to proceed will not succeed even if he has small class sizes." S26

\section{Discussion and Conclusion}

In this study, findings regarding the teaching-learning process of the Methods of Teaching Course were drawn from the observations made by instructor, from the products created by students and their reflections and findings regarding the outcome of this course were obtained from the teacher candidates' opinions. The findings with regard to the process can be considered in terms of two aspects: the delivery of the course as a whole and the changes that occurred within the teacher candidates themselves.

From the point of view of the delivery of the course, it was observed that the teacher candidates derived great satisfaction from the activities conducted in class such as debates, discussions, competitions, 'six thinking hats' technique, and group projects. In particular, the creation of a competitive atmosphere ensured that students played a more active role in tasks and from the moment the activities were started in class to when the class finished, the lesson process was rendered more fun and desirable for students. At the same time, the activities mentioned above ensured that the topic could be presented and knowledge could be captured in a more holistic fashion and played an important role in helping students to internalize and conceptualize subject matter. As regards the change that took place within the teacher candidates themselves, at the beginning, the concept of learning was explained from a more behaviorist approach. In particular, in the case study analysis, they drew attention to the necessity of teacher to be active and importance of repetition for ensuring learning. At the end of the process, the teacher candidates explained the term 'learning' from the constructivist point of view. In this context, in the reflections of the teacher candidates at the end of the course, it was stressed that learning is an individual process, within this process new knowledge is constructed by relating to previous knowledge and teacher fulfill the role of a guide while student himself had to become active. The most challenging activity for the teacher candidates in this course was the preparation of learning plans. In particular, the teacher candidates expressed in their reflections on the course that they had experienced real difficulties in drawing up their initial plans. The main sources of this difficulty that they had experienced were highlighted as follows: they had failed to establish a common language when working in groups, they had encountered difficulties in putting their thoughts 
down in writing, they had experienced problems in finding a suitable subject to apply the method, they had felt anxiety about having to present in front of the class and they were reluctant to encounter negative feedback from the instructor. Especially, in the first learning plan created by the teacher candidates, it was observed that there was a lack of consistency in the determination of objectives, content, organization of learning experience and identification of measurement and evaluation tools and that teaching-learning process in the plans did not let students to foster higher order cognitive levels. However, through the provision of feedback on their products, observation of the good examples submitted by their classmates and analyses of example case studies related to the topic, their products over time improved and the number of flaws and inadequacies in their learning plans declined. When the teacher candidates evaluated their classmates' work at the beginning, it was observed that they paid attention to the criteria such as timing, correct order in which content should be conveyed and the appropriate implementation of the method. However, towards the end of the course, it was observed that they had started to evaluate their classmates' studies in accordance with the criteria such as the inclusion of higher order objectives, the consideration of content and learning experience holistically, and the construction of activities providing the relation of the objectives with real life. On the other hand, the teacher candidates expressed the opinion that they felt certain subjects in their own fields not suitable for the constructivist learning approach and at the end of the process it emerged that they still held the same viewpoint. The teacher candidates brought attention to the view that they felt that especially in subjects requiring the learning of formulae, it was necessary for the teacher to play an active role, and when the teacher did not explain the subject as a whole, it was not, in their opinion, fully understood by students through mere experimentation.

According to the findings derived from the teacher candidates' opinions regarding the constructivist learning approach, they defined mostly the approach by relating to constructivist learning theory. In this context, the constructivist learning approach was defined as one that allowing student to construct and understand knowledge by experiencing this knowledge in his own life and associating it with student's prior knowledge. In fact, one of the basic principles of the constructivist learning theory requires student to understand knowledge and experiences through relating them with his prior knowledge or to construct new schemes (Arslan, 2007; Erdem \& Demirel, 2002; Golding, 2011; Oguz, 2009; Smith III, Disessa \& Roschelle, 1994). Moreover, in the definition submitted by the teacher candidates, it emerged that great emphasis was placed on the roles of the teacher and students. In this regard, teacher has role of a guide, while student adopts an active role in his learning and becomes responsible for it. In a study by Kabapinar (2012) in which he examined the opinions of teacher candidates with regard to the constructivist approach, it was emphasized that in the constructivist approach the teacher acts as facilitator and guide, while the student takes on an active role. Within the scope of this research, the teacher candidates were always granted by right to express their views concerning the lesson content and objectives, organization of learning environments and measurement and evaluation processes. While responsibility was given to them with regard to their own learning, the instructor acted as a guide to the process. Therefore, the findings obtained are thought to be a reflection of this situation. Finally, in the definitions of constructivist learning approach, they attached attention to learning environment characteristics that individual differences are taken into account, cooperative, democratic and student-centered learning exists, process and product evaluation are conducted regularly. Actually, throughout this course, activities that brought out the teacher candidates' their own characteristics were used, group works based on cooperative learning principles were carried out, a comfortable and free learning environment was provided. Such experiences they live in the course may have led them to take into account this classroom atmosphere in their conceptualization of constructivism. In short, in the abovementioned definitions, while the approach was considered from different aspects, misconceptions of the constructivism approach were not encountered. In this respect, it is considered that this study in which the teacher candidates were exposed to learn and experience the constructivist learning approach by experiencing was effective.

The teacher candidates, in general, expressed the view that the constructivist learning approach can render positive contributions to students in three main respects: "cognitive, academic and personal development. As regards the cognitive aspects of the approach, higher order thinking skills such as "conducting research, problem-solving, fostering curiosity and discussion" were emphasized. Dunlap and Grabinger (1996) put forward the view that the learning environment based on constructivism and enriched with active learning ensures students be able to create information and become accustomed to employing high-level thinking skills. As regards the academic aspect, they cited contributions such as being active and participatory, self-regulation, taking responsibility for one's learning, a moving away from rote learning, relating knowledge one has learned to his daily life, using knowledge, posing questions, learning by experiencing and doing, long term and meaningful learning, having positive attitude toward the course, being motivated and the skill of learning to learn were emphasized. The reason for these expressions might be stemmed from the self-reflections done after each activity in which they were asked make reflections regarding their own learning processes and make evaluations regarding how much they had developed. In short, they might have reflected the change, which occurred to them as a result of their experiences, to their responses. In line with these results, Caprio (cited in Hanley, 1994) observed that university students who had been exposed to a constructivist education 
participated in lessons with more desire and enthusiasm took more responsibility for their own learning and organized their own learning processes more effectively. Moreover, the teacher candidates concurred on that the employment of constructive learning contributed to the personal development in addition to academic and cognitive development. Under the heading of personal development, concepts such as self-efficacy, self-confidence, presentation skills, communication skills, self-respect and self-actualization were included. These characteristics include mostly social and affective skills. The teacher candidates throughout the course of the research carried out group work activities. The success of the group was dependent on the contribution of each individual. For this reason, the individuals, both to relieve themselves from pressure from other group members and to become more successful, realized the importance of the skills mentioned above. Furthermore, in the evaluation of the group products, these skills were taken as criteria of evaluation and their importance was emphasized continuously. Moreover, through experience of working together, the group members saw that those who possessed the above-mentioned skills generally created more successful products.

At the head of the list of the limitations that are encountered within the constructivist learning environment were indicated as the difference of students' readiness level. To express this in more simple terms, the teacher candidates expressed the view that the presence of students in the same classes with extreme differences in the way that they learn would not be catered for through the constructivist approach. The main reason that the teacher candidates think in such a way was related to a conceptual misunderstanding originating from the meaning of the term prior knowledge. The teacher candidates demonstrated that, in keeping with traditionalist approaches, they believed that students should all have arrived at the same point by the end of the learning process. Whereas one of the most fundamental principles of the approach is the importance of individual differences as student is seen to be at the center of the constructivist approach (McInerney, 2104, Oguz, 2009). With this in mind, the individual differences between the students must be taken into consideration and in this regard a diversification of teaching methods and techniques is suggested. At the same time, in keeping with the very essence of constructivist learning, there is no set requirement that every student should reach the same point. Another limitation cited with regard to the approach was the crowded nature of classes. The teacher candidates emphasized the fact that in crowded classes it was difficult to address every student in an equal and sufficient manner and for this reason the approach will not have the desired effect on the student. Research studies supporting this finding can also be located within the related studies (Kasapoglu, 2010; Korkmaz, 2008; Unal \& Akpinar, 2006; Yaman, 2009). Another factor that emerged from the teacher candidates' responses and preventing the successful realization of the constructivist approach was group activities that might have involving students who were more inclined to individual study. In a study conducted by Yaman (2009) about the implementation of the new primary school program, teachers expressed the view that students with low levels of self-confidence or being reticent in taking responsibility were being left behind. The teacher candidates had participated in a number of group activities in this study. In the evaluations, no matter how much space was allocated to individual evaluation, the quality of the products created by the group had a greater effect on their success. It was observed by the teacher candidates that those groups who established effective communication, succeeded in the resolution of conflicts, carried out a fair division of work and recognized group and individual responsibility created the best products. A large number of teacher candidates also highlighted that in their previous education life they had not carried out such group work as in this course and they felt inadequate in managing group work time to time, thus, felt unhappy. The teacher candidates in their self-evaluations accepted the main principles of group works and expressed the need to make efforts to teach these principles within the teaching process. However, they expressed the feeling that in their professional life, they may experience difficulties in developing group work skills in their students. Apart from these problems, they stressed that traditional learning habits stemmed from especially teachers and students are totally different from the roles of student and teacher in the constructivist approach and this would cause important problems in the successful implementation of the constructivist approach. As a matter of fact, the student who in the traditional approach recognizes the teacher's role as supreme, is faced with a situation within the constructivist approach whereby the teacher functions as a guide and the student is expected to play an active role. For the change in these roles to be realized, it was argued that time would be needed. Moreover, the teacher candidates emphasized the importance of the internalization of the main tenets of the approach by teachers. Within this process, the teacher is forced to change his expectations from the students; on the other hand if the teacher endeavors to realize a constructivist approach and then defines his expectations in keeping with the criteria of the traditionalist system, the change will be unsuccessful and it will lead to confusion on the part of the students. According to Brooks and Brooks (1999), since most educators were raised for teaching through traditional educational methods, it is expected from these educators to encounter difficulties on the road to become constructivist teachers.

Within the context of science teaching, the teacher candidates also put forward the view that the constructivist approach was suitable for delivering courses in the field of science and accompanying subject matter and that introduction of constructivism would serve to improve the quality of teaching and could be employed to ensure a positive contribution to the development of scientific thinking skills. In other words, they emphasized that it was an approach in keeping with the essence of courses in the field of science. Moreover, Bagci-Kilic (2001) and Koseoglu and Kavak (2001) defined the 
constructivist approach as a suitable and effective one for the teaching science. The unsuitability of certain topics, the limited time allocated for carrying out curriculum, the crowded classes and the lack of training on the part of teachers were all cited as factors that may limit the successful implementation of the constructivist approach in courses in the field of science. Additionally, large class sizes, unsuitability of materials and equipment and physical conditions, as well as the inadequacy of teachers were also cited in studies as reasons for limiting scope in the implementation of constructivist instruction (Bayrak \& Bezen, 2013; Korkmaz, 2008; Secken \& Kunduz, 2013; Yasar \& Sozbilir, 2012). Even though in many studies, the constructivist approach may be supported and the importance of its introduction is emphasized for science teaching, doubts have been raised as to its suitability particularly in teaching scientific terminology and removing misconceptions (Duit, 1995). Even, Duit (1995) expressed a concern with regard to the students' conceptualization of scientific terms and development of scientific processes through the execution of the most common application namely the experiment. He argued that it is not possible for students to construct the meaning of concepts and remove misconceptions at a time; much more repetition and time are required. Finally, the teacher candidates, also brought attention to a number of points regarding the application of the approach in teaching science such as characteristics of students and learning environment, the objectives, content, teaching and learning process and measurement and evaluation tools of the courses in the field of science. In their view for the approach to be applied in a successful way, the student must be moved to the center of the learning process, topics to be taught must be analyzed, and students' expectations must be taken to be different from those at the heart of the traditional approach. They indicated that when planning the lesson, teacher should focus on the question "what activities can I organize so that the student can gain meaning from the topic" rather than asking "what activities should I organize to teach the topic". They also expressed that the learning environment played an important role with respect to the objectives of science lessons. From the point of view, they stated that laboratories need to be adequately equipped and fitted but creating a suitable learning environment that will take place outside the traditional classroom setting would be important for the attainment of the objectives of the course in the field of science. The importance of the learning environment was stressed in that it facilitates the comfortable expression of thoughts and opinions on the part of the students, creates an environment of 'democratic learning' and constitutes a vital factor in ensuring the smooth process of learning.

The teacher candidates pointed out that the new programs of courses in the science field in the secondary education have been simplified in terms of the content but the curriculum still remains very intensive and 'heavy' and thus attention is attached more to subject detail than to the carrying out of in-class practical activities. The problem of the intensity of the curriculum in main branch science lessons such as Science and Technology, Physics, Chemistry and Biology has already been highlighted in the related research (Cepni, Kaya \& Kucuk, 2005; Gunes, Dilek, Hoplan \& Gunes, 2012; Secken \& Kunduz, 2013). On the other hand, it was identified that the volume of subject material has been reduced in the revised programs of Physics, Chemistry and Biology course in 2013-2014 (Bayrak \& Bezen, 2013). In the answers provided by teacher candidates, it was revealed that in order that the constructivist approach can serve to provide education at the level envisaged, it was necessary to simplify the current content of the subject programs. At the same time, the teacher candidates emphasized the importance of adopting objectives so as to raise higher-level skills, the necessity of incorporating skills such as learning to learn, critical thinking, empathy into the learning process and the design of learning-teaching process based on the student-centered methods and techniques. The teacher candidates also expressed the view that the evaluation of both product and process must take place simultaneously. In particular, with respect to their reflections concerning evaluation, feedback and peer evaluation was seen to hold great importance in the development of students.

Concerning the ability to apply the approach in the Turkish educational system, the views of the teacher candidates were grouped under two main headings: factors that prevent implementation and situations that ensure its implementation. Among the factors that were seen as preventing successful implementation of the constructivist approach in Turkey were traditional teachers who had reached retirement age and proved unwilling to abandon their traditional approaches and young teachers who felt that the approach would only bring extra burden to the teaching process and so tended to shy away from additional responsibilities. On the other hand, the teacher candidates expressed their reservations that they had themselves never experienced this kind of education during their educational life, neither in the university faculties from which they had graduated, nor during their school experience. They did not feel they had received adequate training or guidance regarding the approach; thus they felt incapable of teaching lessons based on this approach. The characteristics of the students themselves were cited as another factor that acts to prevent the successful application of this approach. The learning style that students are accustomed to was seen to be an obstacle to effective introduction of an approach which relies on individual differences and elicits students' personal expectations. As previously mentioned with regard to science education, the inadequate provision of technology, the absence of specialized laboratories and overcrowded classes all represented factors that prevent the effective implementation of the constructivist approach, not only in science lessons but also in other areas of the curriculum. In particular, teacher candidates brought attention to the centralized exam system that starts from middle school and continues until the 
teacher recruitment stage and this was cited as the most significant factor that would prevent successful implementation of the approach. The participants expressed the regret that on account of the KPSS exam, teacher candidates focused on theoretical knowledge in pedagogical courses rather than teaching practice. Since teacher candidates learn the topic in this theoretical way, they see a need to approach teaching in the same way when they embark upon their careers (Yildirim, 2011; Yilmaz, 2010). Because of taking the KPSS exam as the main reference, it is observed that in teacher training importance is attached to the theoretical aspects of the subject while application of educational principles remains neglected. Furthermore attention was drawn by the teacher candidates to the other centralized exams such as TEOG, LGS and LYS that are designed according to a multiple-choice format and indicated that on account of giving more importance to these exams, teachers tend to adopt a subject-centered rather than a student-center approach. The fact that the exam system exerts a negative influence on constructivist-based science education has already been covered in detail in other academic studies (Ayvaci, 2010; Ayvaci \& Devecioglu, 2013; Duru \& Korkmaz, 2010). In a study conducted by Altun and Buyukduman (2007), traditional pencil and paper exams do not constitute a suitable tool of measurement within a constructivist learning approach, as constructivism prioritizes process evaluation, not only product, and thus constructivism could be implemented in a more effective manner if the exam-focused education system is abolished.

The results of the research are to be taken as a starting point from which a number of suggestions may be developed with view to putting the approach more effectively into practice. Teacher education programs should ensure students experience this approach so that teacher candidates internalize the main tenets of the constructivist learning approach and become more capable of effectively putting it into practice. Furthermore, in keeping with the findings, it emerged that teacher candidates had knowledge about the approach but felt apprehension and unease when asked to put that knowledge into practice. In order to reduce these misgivings, students need to encounter more frequently constructivist approach-based teaching during their own learning experiences. At the same time, for those teachers already employed in schools, it may be advantageous for them to receive practical in-service training on the constructivist approach that may help them in their implementation. It is possible to establish learning communities about various applications related to the constructivist approach so that they would be able to share their experiences. The teacher candidates expressed the view that there exists a direct relationship between the thinking skills engendered by the constructivist approach and the skills that are required for the courses in the field of science. For this reason, the constructivist approach is important for these courses at every stage of the educational system in order for the attainment of these courses' objectives. Nevertheless, for the effective application of the approach, there is a need to provide technological infrastructure and the necessary equipment and materials.

Further suggestions that will shed light on new research areas can be made based the study results. This study was an action research that progressed in accordance with the course under study with the aim of improving the course and the results revealed that the course based on the constructivist learning approach and the teacher candidates taking this course showed improvement. Therefore, widely use of action research is strongly suggested for educators and researchers who carry out research aiming to develop a course, lesson, program or curriculum. Moreover, in this study, it appeared that there is a contradiction between the expectations of the constructivist learning approach from students and those of the current education system. In a further study related to this issue, this situation may be searched in a descriptive and detailed manner. This study was limited to the opinions of the teacher candidates who were exposed to the constructivist approach. However, in another study, the opinions of teacher candidates in a course based on the constructivist approach can be compared with those of teacher candidates who were instructed in classes where the constructive approach was not implemented. In new studies, those teacher candidates who learned in accordance with the constructive approach should be monitored after graduation in order to determine to what degree they employ the approach in their teaching by using qualitative and quantitative methods.

\section{References}

Abdal-Haqq, I. (1998). Constructivism in teacher education: Considerations for those who would link practice to theory. ERIC Clearinghouse on Teaching and Teacher Education Washington DC. ERIC Document Reproduction Service No. ED426986.

Altun, S., \& Buyukduman, I. (2007). Yapilandirmaci ogretim tasarimi uygulamasina ilisikin ogrenci ve ogretmen gorusleri: Bir ornek olay incelemesi [Teacher and student beliefs on constructivist instructional design: A case study]. Kuram ve Uygulamada Egitim Bilimleri Dergisi, 7(1), 7-39.

Arslan, M. (2007). Egitimde yapilandirmaci yaklasimlar [Constructivist approaches in education]. Ankara Universitesi Egitim Bilimleri Fakultesi Dergisi, 40(1), 41-61.

Aytac, T. (2000). Hizmet ici egitim kavrami ve uygulamada karsilasilan sorunlar [In-service training concept and problems encountered in practice]. Milli Egitim Dergisi, 147, 66-69. 
Ayvaci, H. S. (2010). Fizik ogretmenlerinin baglam temelli yaklasim hakkindaki gorusleri [Views of physics teachers about context based approach]. Dicle Universitesi Ziya Gokalp Egitim Fakultesi Dergisi, 15(2010), 42-51.

Ayvaci, H. S., \& Devecioglu, Y. (2013). 10. sinif fizik ders kitabi ve kitaptaki etkinliklerin uygulanabilirligi hakkinda ogretmen degerlendirmeleri [Teachers' evaluations on 10th grade physics textbook and applicability of activities in the textbook]. Amasya Universitesi Egitim Fakultesi Dergisi, 2(2), 418-450.

Bagci-Kilic, G. (2001). Olusturmaci fen ogretimi [Constructivist science teaching]. Kuram ve Uygulamada Egitim Bilimleri, 1, 7-22.

Bal, A. P. (2008). Yeni ilkogretim matematik ogretim programinin ogretmen gorusleri acisindan degerlendirilmesi [The evaluation of new mathematic curriculum in term of teachers' perspectives]. Çukurova Universitesi Sosyal Bilimler Enstitusu Dergisi, 17(1), 53-68.

Bayrak, C., \& Bezen, S. (2013). 9. sinif fizik ogretim programinda yer alan konularin ogretiminde karsilasilan sorunlara ve yeni ogretim programina yonelik ogretmen gorusleri [Teacher opinions on the latest curriculum and the problems experienced in teaching grade 11 physics curriculum topics]. Hacettepe Universitesi Egitim Fakultesi Dergisi, Ozel Sayi (1), 27-38.

Berg, B. L., \& Lune, H. (2012). Qualitative research methods for the social sciences (8th ed.). Boston, MA: Pearson Education.

Birinci-Konur, K. (2010). Kavramsal degisim metinlerinin sinif ogretmeni adaylarinin fiziksel ve kimyasal degisme konusunu anlamalarina etkisi [The effect of conceptual change texts on the pre-service primary teachers' understanding of physical and chemical change topics]. Unpublished doctoral dissertation, Karadeniz Technical University, Trabzon, Turkey.

Boke, K. (2009). Sosyal bilimlerde arastirma yontemleri [Research methods in social sciences] Istanbul: Melisa Matbaacilik.

Boydak, M. (1999). Hizmet ici egitim programlarinin etkiliginin degerlendirilmesi: Firat, Gazi, Marmara Universitesi ve TUBITAK ornegi [The Evaluation of the efficiency of in-service: The sample of Firat, Gazi, Marmara and TUBITAK]. Unpublished doctoral dissertation, Firat University, Elazig, Turkey.

Brooks, J. G., \& Brooks, M. G. (1999) In search of understanding the case for constructivist classrooms. Alexandria, Virginia: Association for Supervision and Curriculum Development Press.

Burns, A.(2010). Doing action research in english language teaching: A guide for practitioners (1th ed.). USA: Routledge.

Cepni, S., Kaya, A., \& Kucuk, M. (2005). Fizik ogretmenlerinin laboratuvarlara yonelik hizmet ici ihtiyaclarinin belirlenmesi [Determining the physics teachers' in-service needs for laboratories]. Turk Egitim Bilimleri Dergisi, 3(2), 181-196.

Creswell, J. W. (2012). Educational research: Planning, conducting, and evaluating quantitative and qualitative research. USA: Pearson Education, Inc.

Duit, R. (1995). The constructivist view: A fashionable and fruitful paradigm for science education research and practice. In L.P. Steffe \& J. Gale, Constructivism in education (pp.271-285). New Jersey: Lawrence Erlbaum Associates.

Dunlap, J. C., \& Grabinger, R. S. (1996). Rich environment for active learning in the higher education classrooms. In Brent G. Wilson (Ed.), Constructivist learning environments: Case studies in instructional design (pp.65-81). New Jersey: Educational Technology Publications.

Duru, A., \& Korkmaz, H. (2010). Ogretmenlerin yeni matematik programi hakkindaki gorusleri ve program degisim surecinde karsilasilan zorluklar [Teachers' views about a new mathematics curriculum and difficulties encountering curriculum change]. Hacettepe Universitesi Egitim Fakultesi Dergisi, 38, 67-81.

Erdem, E., \& Demirel, O. (2002). Program gelistirmede yapilandirmacilik yaklasimi [Constructivism in curriculum development]. Hacettepe Universitesi Egitim Fakultesi Dergisi, 23, 81-87.

Eren, A., Ozen, R., \& Karabacak, K. ( 2009). Yapilandirmaci bakis acisiyla hizmet ici egitim: Ihtiyac, kariyer, ogrenme ve motivasyon [In-service education through constructivist viewpoint: Need, career, learning and motivation dimensions]. Bogazici Universitesi Egitim Dergisi, 24(2), 29-48.

Golding, C. (2011). The many faces of constructivist discussion. Educational Philosophy and Theory, 43(5), 467-483. doi: $10.1111 / \mathrm{j} .1469-5812.2008 .00481 . x$ 
Gunes, T., Dilek, N. S., Hoplan, M., \& Gunes, O. (2012). Fen ve teknoloji dersinin ogretmenler tarafindan uygulanmasi uzerine bir arastirma [A study on the instruction of the science and technology course by teachers]. Egitim ve Ogretim Arastirmalari Dergisi, 1 (1), 15-23

Hanley, S. (1994). On constructivism. Retrieved May 12, 2015 from http://www.inform.umd.edu/UMS+State/UMD-projects/essays/Constructivism.txt

Jaworski, B. (1994) Investigating mathematics teaching: A constructivist enquiry. London: Falmer Press

Jonassen, D. H. (1999). Designing constructivist learning environments. In C. M. Reigeluth (Ed.), Instructional design theories and models: A new paradigm of instructional theory, Volume II, pp. 215-239). Mahwah, NJ: Lawrence Erlbaum Associates.

Kabapinar, Y. (2012). An analysis of Turkish prospective teachers' perception of constructivist view of learning and teaching. Education and Science, 37(165), 320-335.

Karadag, E., Deniz, S., Korkmaz, T., \& Deniz, G. (2008). Yapilandirmaci ogrenme yaklasimi: Sinif ogretmenleri gorusleri kapsaminda bir arastirma [Constructivist learning approach: a research on the scope of views of class teachers]. Uludag Universitesi Egitim Fakultesi Dergisi, 21(2), 383-402.

Kasapoglu, K. (2010). Relations between classroom teachers ' attitudes toward change, perceptions of - constructivist curriculum change and implementation of constructivistteaching and learning activities in class at primary school level. Unpublished doctoral dissertation, Middle East Technical University, Ankara, Turkey.

Kildan, A. O., \& Temel, Z. F. (2008). Yapilandirmaci yaklasima dayali olusturulan hizmet ici egitimin ogretmenlerin ogretmenlikle ilgili bazi goruslerine etkisi [The effects of in-service training practices for preschool teachers in line with the constructivist approach to determine teachers' perceptions]. Kastamonu Egitim Dergisi, 16(1), 25-36.

Koc, G. (2006). Yapilandirmaci siniflarda ogretmen-ogrenen rolleri ve etkilesim sistemi [Teacher-learner roles and interaction systems in constructivist classrooms]. Egitim ve Bilim, 31(142), 56-64.

Korkmaz, I. (2008). Evaluation of teachers for restructured elementary curriculum (Grades 1 to 5). Education, 129(2), 250-258.

Koseoglu, F., \& Kavak, N. (2001). Fen ogretiminde yapilandirici yaklasim [Constructivist approach in science teaching]. Gazi Universitesi Gazi Egitim Fakultesi Dergisi, 21(1), 139-148.

Kroll, L. R. (2004). Constructing constructivism: How student-teachers construct ideas of development, knowledge, learning, and teaching. Teachers and Teaching: Theory and Practice, 10(2), 199-221.

Marlowe, B. A., \& Page, M. L. (1998). Creating and sustaining the constructivist classroom. USA: Corwin Press Inc.

Maxwell, J. A. (1996). Qualitative research design: An interactive approach. California: Sage Publications.

McInerney, D. M. (2014). Educational psychology: Constructing learning (6th Ed.). Australia: Pearson.

Oguz, A. (2009). Ogretmen egitimi programlarindaki uygulamalarin yapilandirmaci yaklasima uygunlugunun ogretmen adayi gorusleriyle degerlendirilmesi [An evaluation of the suitability of practices in teacher training programs for the constructivism depending on the teacher trainees' views]. Ankara Universitesi Egitim Bilimleri Fakultesi Dergisi, 42(1), 129-155.

Onen, F., Mertoglu, H., Saka, M., \& Gurdal, A. (2009). Hizmet ici egitimin ogretmenlerin ogretim yontem ve tekniklerine iliskin bilgilerine etkisi: OPYEP ornegi [The effects of in-service training on teachers' knowledge about teaching methods and techniques: OPYEP Case]. Ahi Evran Universitesi Egitim Fakultesi Dergisi, 10(3), 9-23.

Ozden, B. (2012). Yansitici dusunme uygulamalarinin sinif ogretmeni adaylarinin yapilandirmaci ogrenme ortami hazirlama becerilerine etkisi [The influence of reflective thinking practices on prospective classroom teachers' skills in preparation of the constructivist learning environment]. Unpublished dissertation, Marmara University, Istanbul, Turkey. DOI: 10.17051/io.2015.00830.

Punch, F. K. (2005). Sosyal arastirmalara giris: Nitel ve nicel yaklasimlar [Introduction to social research: Qualitative and quantitative approaches]. Ankara: Siyasal Kitabevi.

Secken, N., \& Kunduz, N. (2013). 9. sinif kimya dersi ogretim programlarinin degerlendirilmesi [An evaluation of programs of ninth grade chemistry course]. Hacettepe Universitesi Egitim Fakultesi Dergisi, Ozel Sayi (1), 344-358.

Smith III, J. P., Disessa, A. A., \& Roschelle, J. (1994). Misconceptions reconceived: A constructivist analysis of knowledge in transition. The Journal of the Learning Sciences, 3(2), 115-163. 
Taslidere, E. (2013). The effect of concept cartoon worksheets on students' conceptual understandings of geometrical optics. Education and Science, 38(167), 144-161.

Tsai, C. C. (2002). Nested epistemologies: Science teachers' beliefs of teaching, learning and science. International Journal of Science Education, 24(8), 771-783. DOI: 10.1080/09500690110049132.

Unal, G., \& Akpinar, E. (2006). To what extent science teachers are constructivist in their classrooms? Journal of Baltic Science Education, 2(10), 40-50.

Unsal, H. (2013). Yeni ogretim programlarinin uygulanmasina iliskin sinif ogretmenlerinin gorusleri [Primary school teachers' views about practice of new Turkish primary education curriculum]. Ilkogretim Online, 12(3), 635-658.

Von Glasersfeld, E. (1995). A constructivist approach to teaching. In P. S. Leslie,\& J. Gale (Eds.), Constructivism in education. (pp. 3-15). ABD: Lawrence Erlbaum Associates, Publishers.

Yaman, H. (2009). Teachers' views on the applicability of the Turkish course curriculum in crowded primary classrooms. Educational Sciences: Theory \& Practice, 9(1), 349-359.

Yasar, M. D., \& Sozbilir, M. (2012). 9. Sinif kimya dersi ogretim programindaki yapilandirmaciliga dayali ogelerin ogretmenler tarafindan uygulamaya yansitilmasi [Implementation of the constructivist principles into practice by the teachers in the 9th grade chemistry curriculum]. The Journal of Academic Social Science Studies, 5(7), 789-807.

Yildirim, A. (2011). Ogretmen egitiminde catisma alanlari ve yeniden yapilanma [Competing agendas and reform in teacher education]. Uluslararasi Egitim Programlari ve Ogretim Çalismalari Dergisi, 1(1), 1-17.

Yildirim, A. \& Simsek, H. (2013) Sosyal bilimlerde nitel arastirma yontemleri (9.Baski) [Qualitative research methods in social sciences]. Ankara: Seckin Yayinevi.

Yilmaz, K. (2010). Sosyal bilgiler egitimindeki sorunlar ve cozum onerileri: Ogretim elemanlarinin gorusleri [Issues and suggested solutions in social studies education: views of teaching faculty]. Turk Egitim Bilimleri Dergisi, 8(4), 839-867.

Woolfolk, A. (2004). Educational psychology (9th ed.). USA: Pearson

\section{Appendix A}

Codes, Categories and Themes Extracted From Content Analysis

\begin{tabular}{|c|c|c|}
\hline Themes & Categories & Codes \\
\hline Definition of the & & Thinking, producing ideas \\
\hline Constructivist & & Reaching information through their own efforts \\
\hline \multirow[t]{24}{*}{ Learning Approach } & Learning & Learning by doing and experiencing \\
\hline & & Learning by questioning, producing answers/solutions, searching, discovering \\
\hline & & Constructing knowledge based on prior learning (readiness) \\
\hline & Student rolet & Active \\
\hline & student roles & Responsible of one's own learning \\
\hline & & Guidance \\
\hline & & Not giving ready-made information \\
\hline & & Not being the source of information \\
\hline & & Teaching to generate solutions rather than answers \\
\hline & & Making students active \\
\hline & Teacher roles & Ensuring students' engagement and productivity by various methods \\
\hline & & Encouraging searching \\
\hline & & Preparing environment appropriate for knowledge construction \\
\hline & & Giving feedback \\
\hline & & Having more responsibility \\
\hline & & Having subject, pedagogical and intellectual knowledge, being qualified \\
\hline & & Taking individual differences, interests, needs, and desires into account \\
\hline & & Cooperative \\
\hline & & Student-centered \\
\hline & Terching learning nroces & Problem solving, discussion methods \\
\hline & Ieacning-learning process & Following recent technology \\
\hline & & School as life itself, preparatory for life \\
\hline & & Both process and product evaluation \\
\hline & & Free, comfortable, enjoyable and dynamic learning environment \\
\hline Themes & Categories & Codes \\
\hline \multirow{3}{*}{$\begin{array}{l}\text { Contributions of the } \\
\text { approach to students }\end{array}$} & Cognitive skills & Thinking skills \\
\hline & & Research \\
\hline & & Problem solving \\
\hline
\end{tabular}




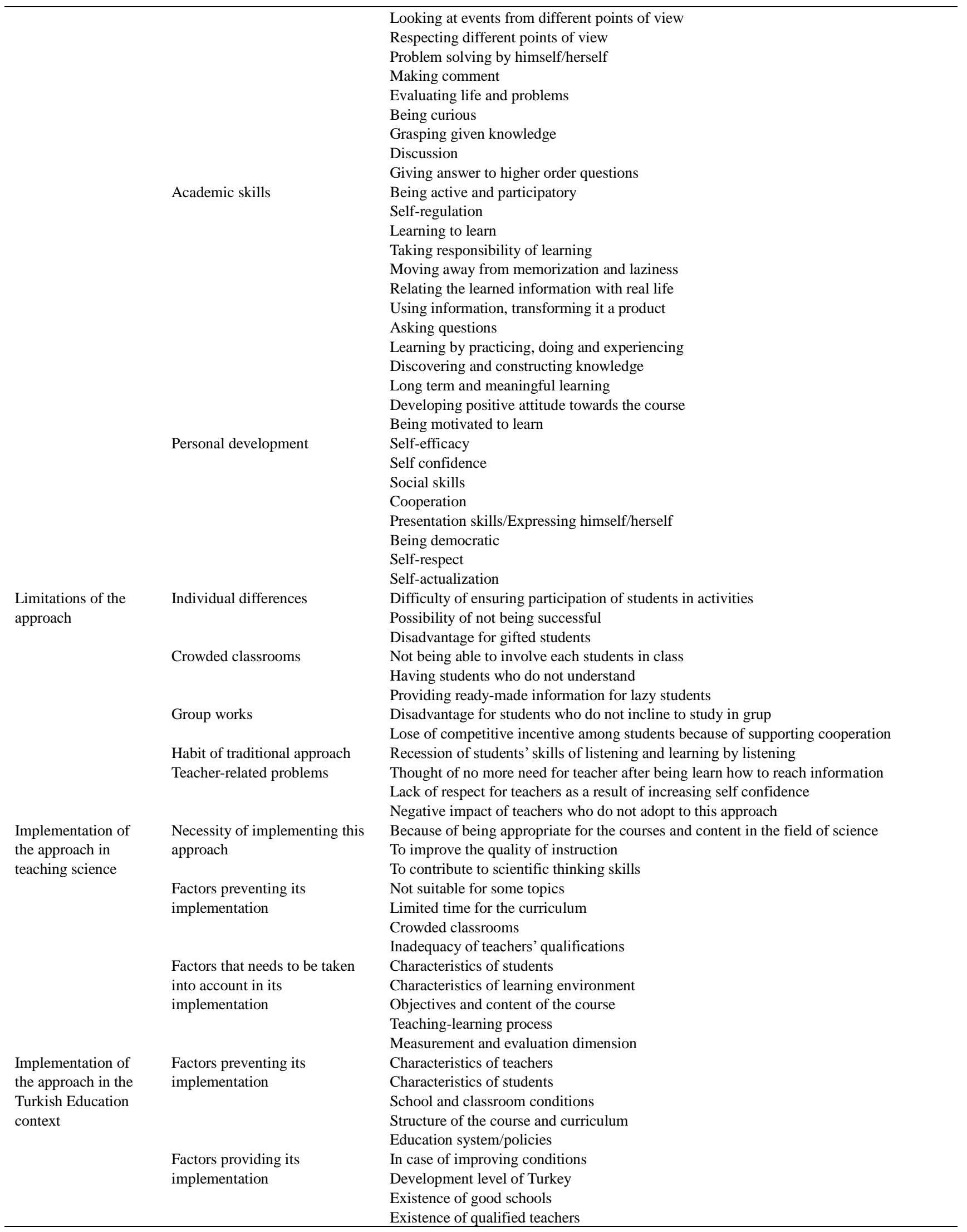

\section{$(\infty)$ EY}

This work is licensed under a Creative Commons Attribution 3.0 License. 